\title{
The multi-year cumulative effects of alternative stocking rate and grazing management practices on pasture productivity and utilization efficiency
}

\author{
B. McCarthy, ${ }^{* 1}$ L. Delaby,‡ K. M. Pierce, $†$ J. McCarthy, ${ }^{\dagger} \dagger$ C. Fleming, ${ }^{*}$ A. Brennan, ${ }^{*}$ and B. Horan* \\ *Animal and Grassland Research and Innovation Centre, Teagasc Moorepark, Fermoy, Co. Cork, Ireland \\ †School of Agriculture and Food Science, University College Dublin, Belfield, Dublin 4, Ireland \\ fINRA, AgroCampus Ouest, UMR 1348, Physiologie, Environnement et Génétique pour l'Animal et les Systèmes d'Elevage, \\ F-35590 Saint-Gilles, France
}

\begin{abstract}
The production and utilization of increased quantities of high quality pasture is of paramount importance in pasture-based milk production systems. The objective of this study was to evaluate the cumulative effects of alternative integrated grazing strategies, incorporating alternative stocking rate (SR) and grazing severities, on pasture productivity and grazing efficiency over multiple years within farm systems using perennial ryegrass dominant pastures. Three whole-farm SR treatments were compared over 4 complete grazing seasons (2009 to 2012 inclusive): low (2.51 cows/ha; LSR), medium (2.92 cows/ha; MSR), and high (3.28 cows/ha; HSR). Each system had its own farmlet containing 18 paddocks and remained on the same treatment for the duration of the study. Stocking rate had a significant effect on all grazing variables with the exception of soil fertility status and sward density. Increased SR resulted in increased total annual net pasture accumulation, improved sward nutritive value, and increased grazed pasture utilization. Total annual net pasture accumulation was greatest in HSR $[15,410 \mathrm{~kg}$ of dry matter $(\mathrm{DM}) / \mathrm{ha}$, intermediate for MSR $(14,992 \mathrm{~kg}$ of DM/ ha), and least for LSR $(14,479 \mathrm{~kg}$ of DM/ha) during the 4-yr study period. A linear effect of SR on net pasture accumulation was detected with an increase in net pasture accumulation of $1,164.4(\mathrm{SE}=432.7) \mathrm{kg}$ of $\mathrm{DM} /$ ha for each $1 \mathrm{cow} /$ ha increase in SR. Pregrazing pasture mass and height and postgrazing residual pasture mass and height were greatest for LSR, intermediate for the MSR, and lowest for the HSR. In comparison with the LSR, the imposition of a consistently increased grazing severity coupled with increased whole farm SR in MSR and HSR treatments arrested the decline in sward nutritive value, typically observed during mid-season. Incorporating the individual beneficial effects of SR on pasture accumulation, nutritive value, and utilization
\end{abstract}

Received April 29, 2015.

Accepted December 2, 2015.

${ }^{1}$ Corresponding author: brian.mccarthy@teagasc.ie efficiency, total proportional energy (unité fourragère lait) utilization per hectare increased significantly with increasing SR $(+0.026$ and +0.081 for MSR and HSR, respectively). These results quantify the significant effect of grazing management practices on the feed production capability of modern perennial ryegrass pastures for intensive grazing dairy production systems. Furthermore, these results highlight the importance of consistently imposing grazing treatments over multiple years, and within integrated whole farm systems, to accurately assess the longer term effects of alternate grazing management practices on pasture productivity. Key words: stocking rate, grazing severity, sward nutritive value, pasture production and utilization

\section{INTRODUCTION}

Worldwide demand for dairy products has been increasing rapidly as a result of projected population growth, urbanization, and increases in per capita disposable income (Rae, 2002; Delgado, 2005). Commensurate with the increased global food demand, increased competition for land, water, and energy resources necessitates that global agricultural production becomes more productive based on systems that are also more environmentally and socially sustainable. In this regard, awareness is increasing of the multifunctional character and benefits of pasture-based farming (Jeangros and Thomet, 2004) due to its capability to be both highly productive (Macdonald et al., 2008; McCarthy et al., 2013a), environmentally benign (Nosberger and Rodriguez, 1996; Jankowska-Huflejt, 2006; Peyraud et al., 2010), financially efficient (Dartt et al., 1999; Dillon et al., 2008), and socially sustainable (Dartt et al., 1999; White et al., 2002), while providing products with advantageous nutritional characteristics (O'Brien et al., 1999; Coakley et al., 2007). Both Taube et al. (2013) and Baumont et al. (2014) have suggested that systemic improvements in pasture-based food production efficiency can be ascertained by increasing pasture utilization and placing less emphasis on external supplementary feed and fertilizer inputs. 
The efficient production of milk from grazing systems is dependent on the extensive use of cheap high-quality grazed pasture (Horan et al., 2005; Dillon et al., 2008). Previous studies have indicated that, in comparison with mechanically harvested or purchased feeds, grazed pastures provide a relatively inexpensive and energy efficient feed source for milk production (Dillon et al., 2008; Ramsbottom et al., 2015). The production performance of grazing systems is heavily reliant on the yield of utilizable energy and protein from grazed pastures and is consequently reliant on prevailing climatic conditions (Roche et al. 2009), which are beyond the control of the grassland farmer. Such inherent temporal variability necessitates the identification of grazing management practices that increase the yield and stability of high quality pasture to enhance the robustness and predictability of grazing systems in the future.

The agronomic objectives of technically efficient grazing management have been extensively studied and reviewed in the literature and the immediate influence of individual grazing management components on pasture accumulation, nutritive value, and utilization has been reported (Lee et al., 2007; Ganche et al., 2013b; Tuñon, 2013). Stocking rate (SR), defined as the number of animals per unit area of land used during a specified defined period of time (cows/ha, Allen et al., 2011) is widely acknowledged as the main driver of productivity from grazing systems (Hoden et al., 1991; Macdonald et al., 2008; Baudracco et al., 2010). Increasing SR is usually associated with an increase in grazing severity, and many studies have attributed the increased productivity of higher SR systems to an improvement in pasture utilization (Hoden et al., 1991; Macdonald et al., 2008). In contrast, the effect of increasing SR and defoliation severity on pasture production has been extensively studied but inconsistently reported (Donaghy and Fulkerson, 1998; Macdonald et al., 2008; Lee et al., 2009), and the evaluation of such effects is often complicated by alternative grazing decision rules (Clark et al., 2010) and the difficulties of extending the results of shorter term component-based or cutting experiments to field conditions (Anderson and Briske, 1995). Indeed, previous studies have also indicated that although variation in defoliation and plant regrowth patterns creates variability in sward structure and nutritive value (Possingham and Houston, 1990; Adler et al., 2001), the effects of such practices are frequently accentuated by the farm system SR (Laca and Demment, 1991). Despite the critical importance of grazing management practices to grazing science, and evidence of longer term conditioning effects of these practices (Hoogendoorn et al., 1992; Pulido and Leaver, 2003; Stakelum and Dillon, 2007), the integration and evaluation of alternative SR and grazing practice combina- tions over multiple years to evaluate the cumulative systemic effects on pasture productivity have seldom been undertaken.

Consequently, the objective of this study is to evaluate the cumulative effects of alternative integrated grazing strategies, incorporating alternative SR and grazing severities, on grassland productivity and grazing efficiency over multiple years within farm systems using perennial ryegrass dominant pastures.

\section{MATERIALS AND METHODS}

This study was undertaken at the Animal and Grassland Research and Innovation center, Teagasc Moorepark, Ireland $\left(50^{\circ} 7 \mathrm{~N} ; 8^{\circ} 16 \mathrm{~W}\right)$, over a 4 -yr period $(2009$, 2010, 2011, and 2012). It formed part of a larger study designed to examine the biological and economic effects of alternative SR grassland systems, and a more detailed description of the animals, treatment, and experimental design has been reported previously (McCarthy et al., 2012). The on-site pastures used were predominantly perennial ryegrass (Lolium perenne L.) and had been reseeded over the previous 1 to $9 \mathrm{yr}$.

\section{Experimental Design, Treatments, and Herd Management}

In spring 2009, 138 high economic breeding index spring-calving Holstein-Friesian dairy cows were randomly assigned precalving based on parity, expected calving date, and economic breeding index to 1 of 3 whole farm SR treatments: low (2.51 cows/ha; LSR), medium (2.92 cows/ha; MSR), and high (3.28 cows/ ha; HSR). Treatments were designed to represent alternative whole-farm SR that may be appropriate in a post-European Union milk quota, spring-calving, pasture-based milk production system. The experimental herd in the study was composed of elite animals (McCarthy et al., 2013b) and was managed with a compact spring-calving pattern that was closely aligned with the average pasture growth capacity of the site $(50 \%$ of all animals calving in the first 2 wk of February, $90 \%$ calved by mid-March, and with a mean calving date of February 20). As a pasture-based production system, grazing commenced as cows calved in early February and the grazing season concluded in late November of each year. During December and January, all cows were dried off and housed on a diet of conserved pasture silage.

\section{Grazing, Nutrient, and Feeding Management}

A total of 48.1 ha of permanent grassland, containing greater than $80 \%$ perennial ryegrass, were used for the 
duration of the experiment. Eighteen blocks were created, balanced on location, pasture age, and soil type. Within each block, paddocks were randomly assigned to SR treatment to create a farmlet for each treatment, and paddocks remained in the same treatment farmlet for the duration of the experiment. Total farmlet areas for the LSR, MSR, and HSR were 18.4, 15.8, and 14.0 ha, respectively. Grazing management was accomplished by weekly monitoring of farm pasture cover within each SR treatment (O'Donovan, 2000). Similar to previous whole farm SR studies (Macdonald et al., 2008), weekly grazing management during the first rotation in spring (February 1 to April 1) was based on allocating an equal and increasing proportion of each farmlet to each treatment up to the start of rotation 2. To apply the SR effect consistently between paddocks during the main grazing season, the residency time within each paddock, ranging from 1.5 to $2.5 \mathrm{~d}$ per paddock, was determined by achieving the target postgrazing residual sward height (LSR $=45$ to $50 \mathrm{~mm}$, MSR $=40$ to $45 \mathrm{~mm}$, and HSR 35 to $40 \mathrm{~mm}$ ), and each group was moved independently of one another to the next paddock once this target was reached. Target pregrazing pasture mass was defined separately for each SR according to the following equation:

target pregrazing pasture mass $=[\mathrm{SR}$; cows $/$

ha $\times$ ideal rotation length $(21 \mathrm{~d}$ during main grazing season) $\times$ daily pasture allowance per cow; $\mathrm{kg}$ of DM/ cow per d] + residual pasture mass; kg of DM/ha.

When pregrazing pasture mass in the next grazing paddock exceeded the target level, the paddock was skipped and pasture was harvested as silage. A sample of pasture was taken before baling for DM determination, and bales from each paddock were weighed to give an estimate of the amount of feed conserved from each paddock (Macdonald et al., 2008). No mechanical topping of the pastures took place during the experiment.

Best practice nutrient management was applied to the management of each farmlet within the study and has been reported previously by Heubsch et al. (2013). Chemical $\mathrm{N}$ fertilizer application rates were common across SR treatments at $250 \mathrm{~kg}$ of $\mathrm{N}, 4 \mathrm{~kg}$ of $\mathrm{P}$, and $8 \mathrm{~kg}$ of $\mathrm{K}$ per ha per $\mathrm{yr}$ and were applied according to recommended rates and timings (Teagasc, 2009). During the winter months between late November and early February, all animals were housed and all animal slurry was collected and stored. During periods of excessive rainfall $(>10 \mathrm{~mm} / \mathrm{h})$ during the grazing season, animals were occasionally housed and on-off grazing (Kennedy et al., 2009) was used as a management tool to facilitate grazing and to avoid soil structural damage. All animal slurry generated by the animals during winter was reapplied to each farmlet over the first 4 mo of the following grazing season and at a rate of 19,000 $\mathrm{L} / \mathrm{ha}$ on each farmlet. As the experiment was designed to maintain similar $\mathrm{N}$ inputs to each SR treatment, target concentrate supplementation was similar for each $\mathrm{SR}$ at $850 \mathrm{~kg}$ of DM/ha per yr, and consequently, lower per cow as SR increased. Concentrate supplementation for all treatments commenced at $4 \mathrm{~kg} / \mathrm{cow}$ per d postcalving, and was reduced and removed totally from the diet only when pasture supply exceeded animal demand for all treatments (usually by mid-March). During the main grazing season, concentrate and additional forage supplementation (in the form of baled silage) were occasionally used when pasture supply was in deficit of feed demand. Concentrate supplement was only used when a feed deficit occurred for each SR treatment and a similar supplementation rate per ha was imposed in all treatments on those occasions. When feed deficits arose for individual SR treatments, conserved silage produced within the specific treatment was used to supplement feed supply.

\section{Pasture Measurements}

The grazing period was broken down into 3 distinct seasons: spring (February 1 to March 31), mid-season (April 1 to July 30), and autumn (August 1 to November 20). Spring corresponds to the first rotation where all the area within each farmlet is available for grazing before paddocks are closed off for silage during the summer period. During autumn, the entire farmlet area is again available for grazing. Grazing data were collected on each paddock during each grazing rotation each year according to the procedures outlined by McCarthy et al. (2013b). Pregrazing pasture mass $(>3.5 \mathrm{~cm})$ was determined before grazing on each paddock by harvesting 2 strips $(1.2 \mathrm{~m} \times 10 \mathrm{~m})$ of pasture with an Etesia mower (Etesia UK Ltd., Warwick, UK). All mown pasture from each strip was collected and weighed and a 0.1-kg (fresh weight) subsample was taken and dried for $16 \mathrm{~h}$ at $90^{\circ} \mathrm{C}$ for $\mathrm{DM}$ determination. Ten compressed sward-height (CSH) measurements were recorded before and after harvesting on each cut strip using a rising pasture plate meter with a steel plate (Jenquip, Feilding, New Zealand). Based on the above measurements, sward bulk density (henceforth, sward density) was calculated as follows (Delaby and Peyraud, 1998):

sward density $(\mathrm{kg}$ of $\mathrm{DM} / \mathrm{cm}$ per ha) = pasture mass (kg of DM/ha)/(precutting CSH - postcutting CSH). 
Pre- and postgrazing sward height were determined on each paddock before and after grazing by taking between 30 and 50 height measurements using the rising pasture plate meter across the diagonal of the paddock. The average paddock pregrazing pasture mass above a cutting height of $3.5 \mathrm{~cm}$ ( $\mathrm{kg}$ of $\mathrm{DM} / \mathrm{ha}$ ) was then calculated according to the following formula (Delaby and Peyraud, 1998):

pregrazing pasture mass $(\mathrm{kg}$ of DM/ha) $=$

(pregrazing $\mathrm{CSH}(\mathrm{cm})-3.5 \mathrm{~cm}) \times$ sward density

(kg of DM/cm/ha).

Pasture utilized ( $\mathrm{kg}$ of $\mathrm{DM} / \mathrm{ha}$ ) at each grazing was calculated using the following formula (Delaby and Peyraud, 1998):

$$
\begin{gathered}
\text { pasture utilized }(\mathrm{kg} \text { of } \mathrm{DM} / \mathrm{ha})= \\
\text { (pregrazing } \mathrm{CSH}-\text { postgrazing } \mathrm{CSH}) \\
\times \text { sward density }(\mathrm{kg} \text { of } \mathrm{DM} / \mathrm{cm} \text { per ha). }
\end{gathered}
$$

Net pasture accumulation was calculated weekly from the increase in pasture mass on ungrazed paddocks using the method of O'Donovan (2000). The efficiency of grazing was determined using the method proposed by Delaby and Peyraud [1998; pasture utilized/pregrazing pasture mass $(>3.5 \mathrm{~cm})$ at each grazing]. Pasture utilized was calculated as the difference between the pregrazing pasture mass $(>3.5 \mathrm{~cm})$ and the postgrazing pasture mass (above the postgrazing $\mathrm{CSH}$ ) within the same rotation. Total net pasture utilization was calculated as the sum of the pasture utilized at each grazing for each treatment. Daily net pasture accumulation was calculated by dividing the pasture accumulated between grazings by the inter-grazing interval $(d)$.

\section{Chemical Analyses}

Pasture samples were collected from each paddock, prior to grazing, for each SR treatment and were dried at $40^{\circ} \mathrm{C}$ for $48 \mathrm{~h}$ and milled through a $1-\mathrm{mm}$ sieve. Samples were bulked by SR by week and analyzed for DM, ash, ADF, NDF (Van Soest, 1963), CP (Leco FP-428; Leco Australia Pty Ltd., Baulkham Hills, New South Wales, Australia), and organic matter digestibility (OMD; Morgan et al., 1989). The energy $\left(\mathrm{NE}_{\mathrm{L}}\right.$ expressed as "unité fourragère lait," UFL; Beaumont et al., 2007) value of the pasture within each SR at each grazing was also subsequently calculated. Soil samples were collected (20 cores per plot to a depth of $100 \mathrm{~mm}$ ) in January of each year before fertilizer and slurry ap- plication. Soil available $\mathrm{P}$ and $\mathrm{K}$ were determined using Morgan's extracting solution (10\% Na-acetate in 3\% acetic acid buffered at pH 4.8; Peech and English, 1944; Byrne, 1979) and expressed as milligrams per liter of soil. Soil $\mathrm{pH}$ was also measured according to standard methods (Byrne, 1979).

\section{Meteorological Data}

Daily measurements of average air temperatures and daily rainfall were recorded automatically by a meteorological station approximately $3 \mathrm{~km}$ from the experimental site at the Animal and Grassland Research and Innovation Centre, Teagasc, Moorepark, Fermoy, Co. Cork.

\section{Statistical Analysis}

The effect of SR, season, and year on pregrazing pasture mass, pre- and postgrazing height, grazing efficiency, and the chemical composition of the pasture was determined using mixed models (Proc MIXED, 2006, SAS Institute Inc., Cary, NC) with rotation included as a repeated effect. Individual paddocks were considered as the experimental unit. A compound symmetry covariance structure among records within paddock provided the best fit to the data. Total net pasture accumulation and utilization were also determined using mixed models (Proc MIXED, 2006, SAS Institute Inc.) with block and block $\times$ SR included as random effects. The linear and quadratic effects of SR were also evaluated for both pasture accumulation and net energy utilization by including SR as a continuous variable within the mixed model. Soil $\mathrm{P}$ and $\mathrm{K}$ data were analyzed using a generalized linear model (Proc GLM, 2006, SAS Institute Inc.).

\section{RESULTS}

\section{Climate Data}

Total annual rainfall averaged $1,030 \mathrm{~mm}$ during the 4-yr study period compared with $1,027 \mathrm{~mm}$ during the 2000 to 2010 period. Mean monthly rainfall and temperature data for each year of the study and the 10yr mean are presented in Table 1. Climatic conditions varied significantly between years during the study. During both 2009 and 2012, total rainfall was above the 10-yr average $(+269$ and $+72 \mathrm{~mm}$, respectively) with April (+43 mm), July (+72 mm), August (+42 mm), and November $(+141 \mathrm{~mm})$ in 2009 and June $(+145$ $\mathrm{mm})$ and August (+106 mm) in 2012 being particularly high rainfall months. In contrast, total rainfall was 
Table 1. Monthly total rainfall $(\mathrm{mm})$ and mean soil temperature $\left({ }^{\circ} \mathrm{C}\right)$ during the experimental period compared with the 10 -yr $(2000$ to 2010$)$ average

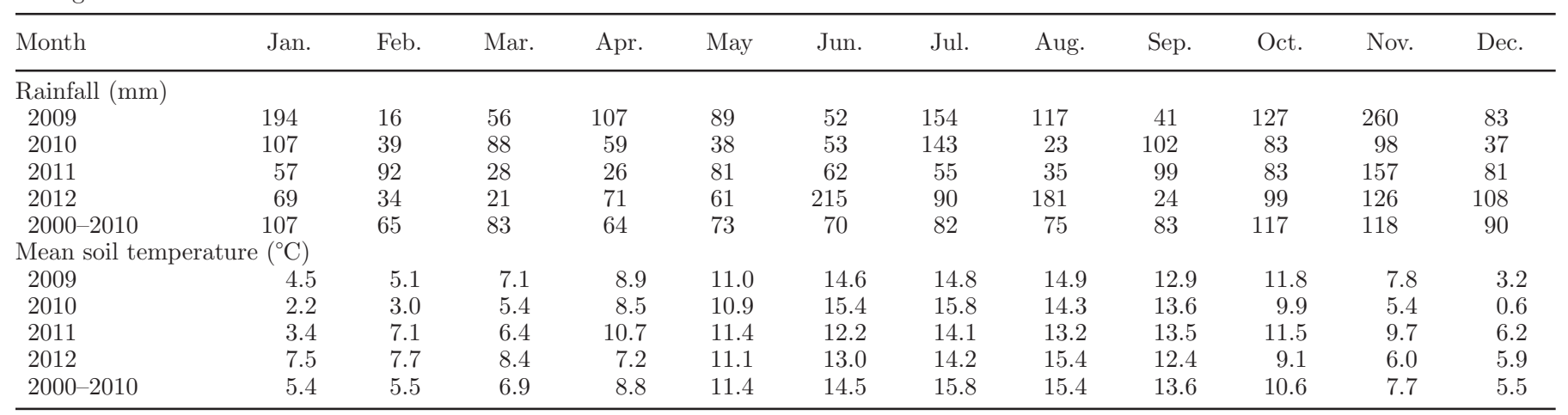

below the 10-yr average in both 2010 and 2011 (-157 and $-171 \mathrm{~mm}$, respectively) with total rainfall in the months of May $(-35 \mathrm{~mm})$, June $(-17 \mathrm{~mm})$, and August $(-52 \mathrm{~mm})$ in 2010 and January $(-60 \mathrm{~mm})$, March $(-55 \mathrm{~mm})$, April $(-38 \mathrm{~mm})$, and August $(-40 \mathrm{~mm})$ in 2011 being particularly low rainfall months. Mean daily temperatures were $0.4,1.3,0.1$, and 0.3 degrees lower than the 10-yr average in 2009, 2010, 2011, and 2012, respectively, with the first 3 mo of 2010 being particularly cold $\left(-2.4^{\circ} \mathrm{C}\right)$.

\section{Grazing Characteristics and Net Pasture Accumulation}

Both SR and year had a significant effect on total annual net pasture accumulation during the study period (Figure 1). Significant paddock to paddock variation in annual net pasture accumulation was evident, ranging from a minimum of $9,749 \mathrm{~kg}$ of $\mathrm{DM} /$ ha to a maximum of $20,208 \mathrm{~kg}$ of $\mathrm{DM} / \mathrm{ha}$ per yr. Annual cumulative net pasture accumulation (SD) was greatest in HSR [15,410 $(2,103) \mathrm{kg}$ of $\mathrm{DM} / \mathrm{ha}]$, intermediate for MSR [14,992 $(2,151) \mathrm{kg}$ of DM/ha], and least for LSR [14,479 $(2,435)$ $\mathrm{kg}$ of $\mathrm{DM} / \mathrm{ha}$ ] during the 4-yr study period. A linear effect $(P<0.001)$ of SR on net pasture accumulation was detected with an increase in net pasture accumulation of $1,164.4(\mathrm{SE}=432.7) \mathrm{kg}$ of $\mathrm{DM} /$ ha for each $1 \mathrm{cow} /$ ha increase in SR. Net pasture accumulation $( \pm S D)$ was 14,442 (2,456), 14,647 (2,004), 14,880 (2,064), and $15,872(2,259) \mathrm{kg}$ of DM/ha during 2009, 2010, 2011, and 2012, respectively. The higher overall net pasture accumulation of MSR and HSR was also consistent through each month of the year (Figure 2). No significant year $\times$ SR treatment interaction was found for grazing characteristics, and consequently only the main effects of SR are detailed in Table 2. Stocking rate had a significant effect on all grazing variables with the exception of sward density $(274 \mathrm{~kg}$ of $\mathrm{DM} / \mathrm{cm}$ per ha). Pregrazing pasture mass and CSH and postgrazing residual sward mass and CSH were greatest for LSR, intermediate for the MSR, and lowest for the HSR ( $P$ $<0.01$ ). Stocking rate treatment had no significant effect on soil fertility parameters, which remained stable during the experimental period (soil $\mathrm{pH}=6.4$, soil $\mathrm{P}$ content $=10.8 \mathrm{mg} / \mathrm{L}$, soil $\mathrm{K}$ content $=122.8 \mathrm{mg} / \mathrm{L})$.

\section{Pasture Nutritive Value}

Both SR and season had a significant effect on pasture nutritive value, and an interaction was also found between SR and season for all of the nutritive value variables measured. The nutritive value of the pasture available $(>3.5 \mathrm{~cm})$ improved as SR increased (Table 3 and Figure 3). Although the absolute differences in nutritive value between treatments were modest, the higher SR treatments consistently produced pasture of increased nutritive value during the study and in particular during mid-season and autumn. Crude protein content was highest $(P<0.001)$ for HSR, intermediate for MSR, and lowest for LSR. Similarly, OMD was greater for HSR compared with both LSR and MSR. The HSR also consistently had the lowest $(P<0.001)$ NDF, ADF, and ash concentration, whereas LSR was highest and MSR was intermediate. As a consequence of the increased OMD, and reduced NDF and ADF content, pasture from the HSR also consistently had the greatest $(P<0.001)$ energy content $(0.96 \mathrm{UFL} /$ $\mathrm{kg}$ of DM), whereas LSR was least $(0.93 \mathrm{UFL} / \mathrm{kg}$ of $\mathrm{DM})$ and MSR was intermediate (0.94 UFL $/ \mathrm{kg}$ of $\mathrm{DM})$. The mean monthly variation in $\mathrm{OMD}, \mathrm{CP}$, and UFL in each SR treatment is presented in Figure 3. Crude protein content was highest in spring (233.3 g/ $\mathrm{kg}$ compared with 202.4 and $204.5 \mathrm{~g} / \mathrm{kg}$ for mid-season and autumn, respectively). Organic matter digestibility was also highest in spring $(790.4 \mathrm{~g} / \mathrm{kg})$, intermediate in mid-season $(787.2 \mathrm{~g} / \mathrm{kg})$, and least in autumn $(761.7 \mathrm{~g} /$ $\mathrm{kg})$. Neutral detergent fiber content was lower in spring and mid-season compared with autumn $(465.0,466.7$, 


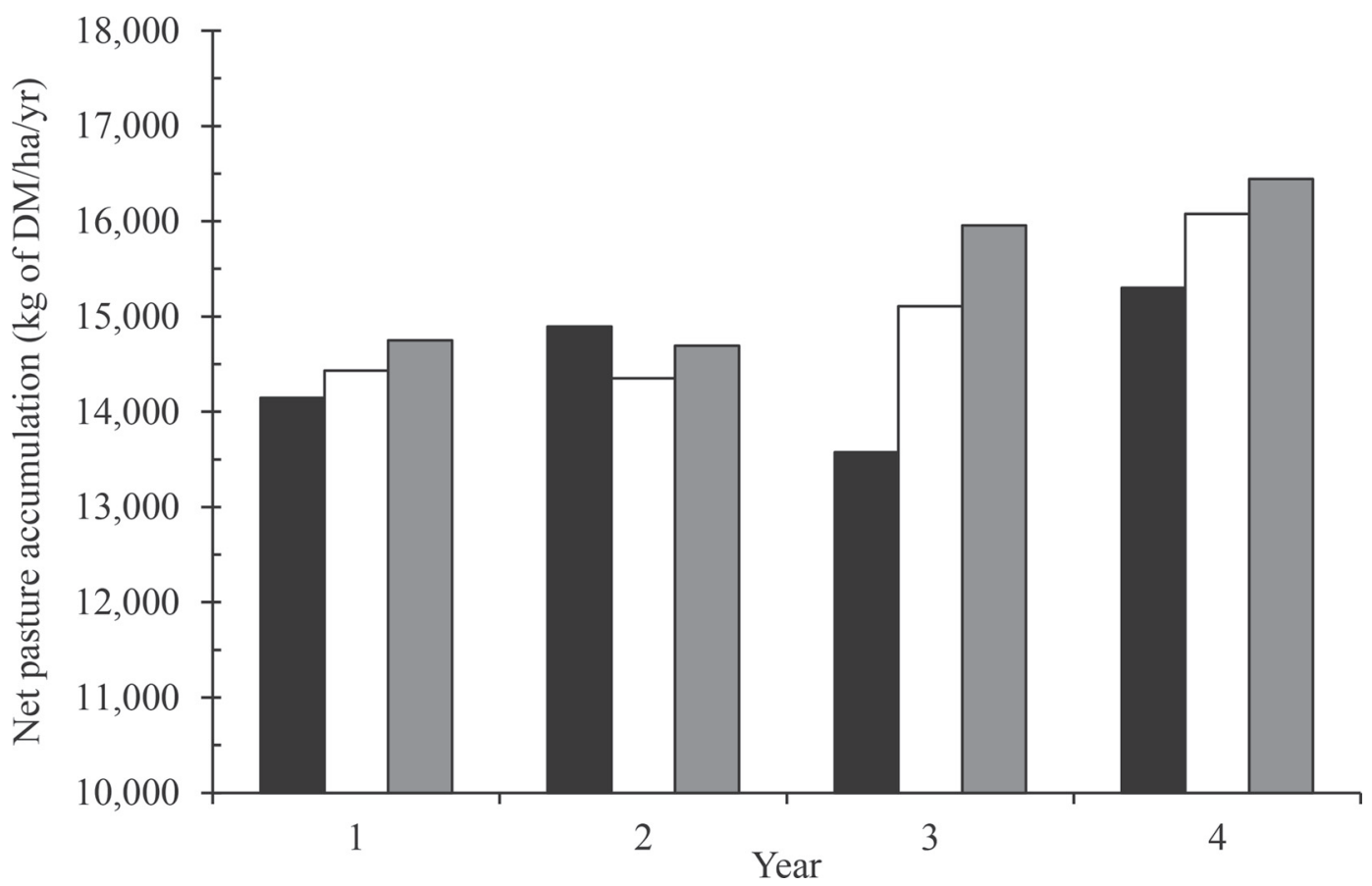

Figure 1. Effect of stocking rate $(\mathrm{SR})$ treatment (low $\mathrm{SR}=2.51$ cows/ha, black bar; medium $\mathrm{SR}=2.92$ cows/ha, white bar; and high SR $=3.28$ cows $/$ ha, gray bar) on annual total net pasture accumulation.

and $485.6 \mathrm{~g} / \mathrm{kg}$, respectively), whereas ADF content was lowest in summer $(269.9 \mathrm{~g} / \mathrm{kg})$, intermediate in spring $(282.2 \mathrm{~g} / \mathrm{kg})$, and highest during autumn $(286.8$ $\mathrm{g} / \mathrm{kg})$. Similar to OMD, ash content of experimental pastures was highest in spring $(156.6 \mathrm{~g} / \mathrm{kg})$, least in autumn $(114.6 \mathrm{~g} / \mathrm{kg})$, and intermediate during mid-season

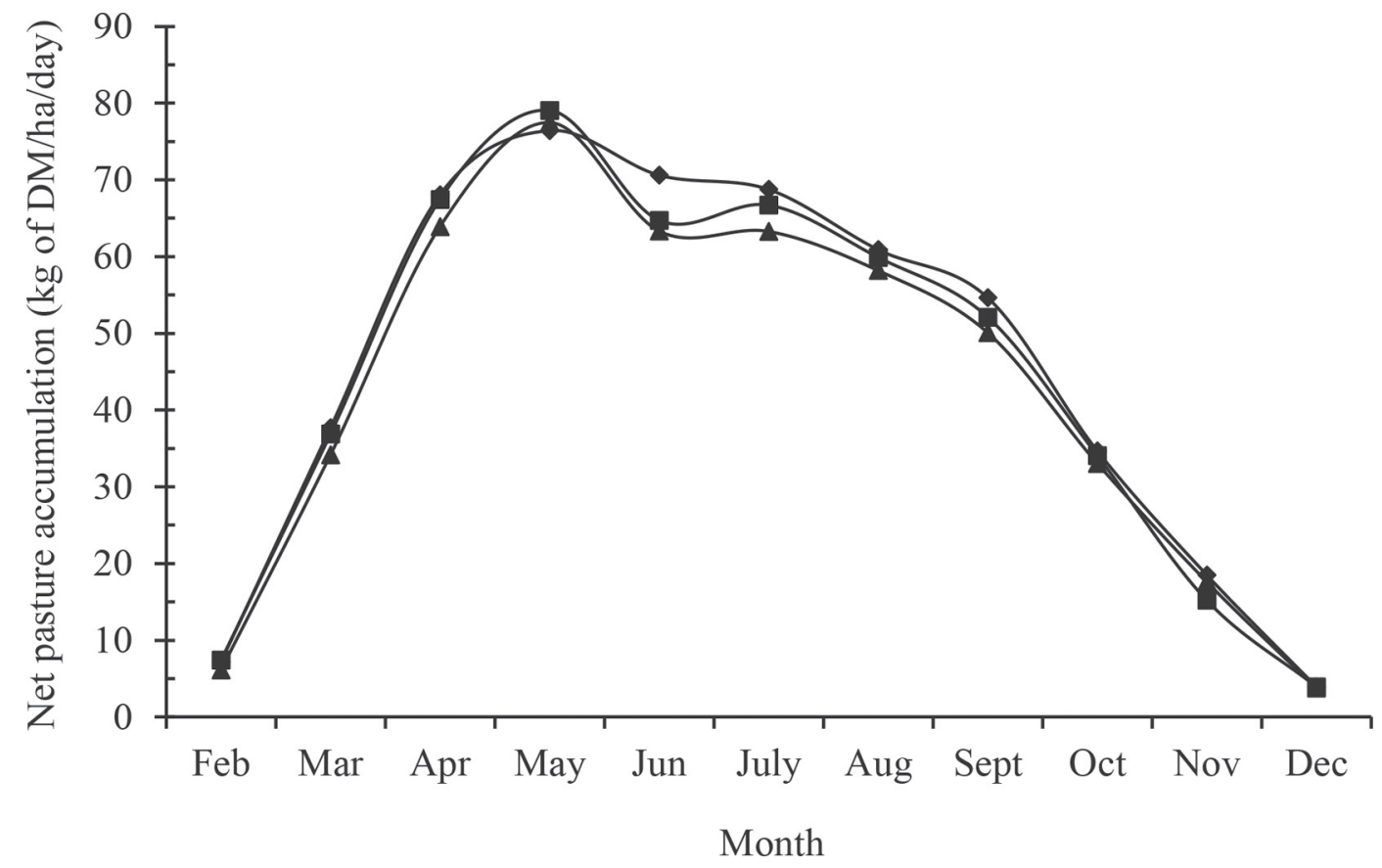

Figure 2. Effect of stocking rate $(\mathrm{SR})$ treatment (low $\mathrm{SR}=2.51 \mathrm{cows} /$ ha, $\mathbf{\Lambda}$; medium $\mathrm{SR}=2.92$ cows/ha, $\mathbf{\square}$; and high SR $=3.28$ cows $/$ ha, -) on mean daily net pasture accumulation during the grazing season. 
Table 2. Effect of stocking rate $(\mathrm{SR})^{1}$ on average pre- and postgrazing pasture mass, sward height, pasture density, and pasture accumulation during 4 complete grazing seasons

\begin{tabular}{|c|c|c|c|c|c|}
\hline \multirow[b]{2}{*}{ Item } & \multicolumn{3}{|c|}{$\mathrm{SR}$} & \multirow[b]{2}{*}{ SEM } & \multirow[b]{2}{*}{$P$-value } \\
\hline & Low & Medium & High & & \\
\hline \multicolumn{6}{|l|}{ Average pregrazing sward characteristics ${ }^{2}$} \\
\hline Pasture mass $(\mathrm{kg}$ of $\mathrm{DM} / \mathrm{ha})$ & 1,505 & 1,448 & 1,451 & 14.5 & 0.01 \\
\hline Sward height (mm) & 88.1 & 87.4 & 86.2 & 0.52 & 0.01 \\
\hline Pasture density ( $\mathrm{kg}$ of $\mathrm{DM} / \mathrm{cm}$ per ha) & 275 & 273 & 274 & 1.1 & 0.42 \\
\hline \multicolumn{6}{|l|}{ Average postgrazing pasture characteristics } \\
\hline Average net pasture accumulation (kg of $\mathrm{DM} / \mathrm{ha}$ ) & 1,298 & 1,325 & 1,401 & 13.8 & 0.001 \\
\hline
\end{tabular}

${ }^{1}$ Stocking rate: low $=2.51$ cows $/$ ha, medium $=2.92$ cows $/$ ha, high $=3.28$ cows $/$ ha .

${ }^{2}$ Estimated based on the method of Delaby and Peyraud (1998).

$(126.3 \mathrm{~g} / \mathrm{kg})$. Finally, the energy content of the pastures grazed during the study were similar in spring and midseason (0.95 and $0.96 \mathrm{UFL} / \mathrm{kg}$ of $\mathrm{DM}$, respectively) but reduced during autumn (0.92 UFL/kg of DM).

\section{Pasture Utilization}

The effect of SR on total and seasonal pasture utilization is presented in Table 4 and the mean monthly preand postgrazing pasture height and grazing efficiency are illustrated in Figure 4. Season had a significant effect on pasture utilization with $58 \%$ of total pasture utilization achieved during mid-season (April to July inclusive, equivalent to $7,231 \mathrm{~kg}$ of $\mathrm{DM} / \mathrm{ha}$ ) compared with just 18\% during spring (January to March inclusive, 2,244 $\mathrm{kg}$ of DM/ha) and $24 \%$ during autumn (August to November inclusive; 2,992 kg of DM/ha). In spring, average pre- and postgrazing pasture masses and postgrazing residual CSH were low for all SR treatments $(788 \mathrm{~kg}$ of DM/ha, $-166 \mathrm{~kg}$ of DM/ha, and 28.7 $\mathrm{mm}$, respectively) compared with mid-season $(1,419 \mathrm{~kg}$ of DM/ha, $150 \mathrm{~kg}$ of DM/ha, and $40.6 \mathrm{~mm}$, respective-

Table 3. Effect of stocking rate $(\mathrm{SR})^{1}$ and season $(\mathrm{S})^{2}$ on pasture $\mathrm{CP}$, organic matter digestibility (OMD), NDF, ADF, ash, and energy content during the 4-yr study period

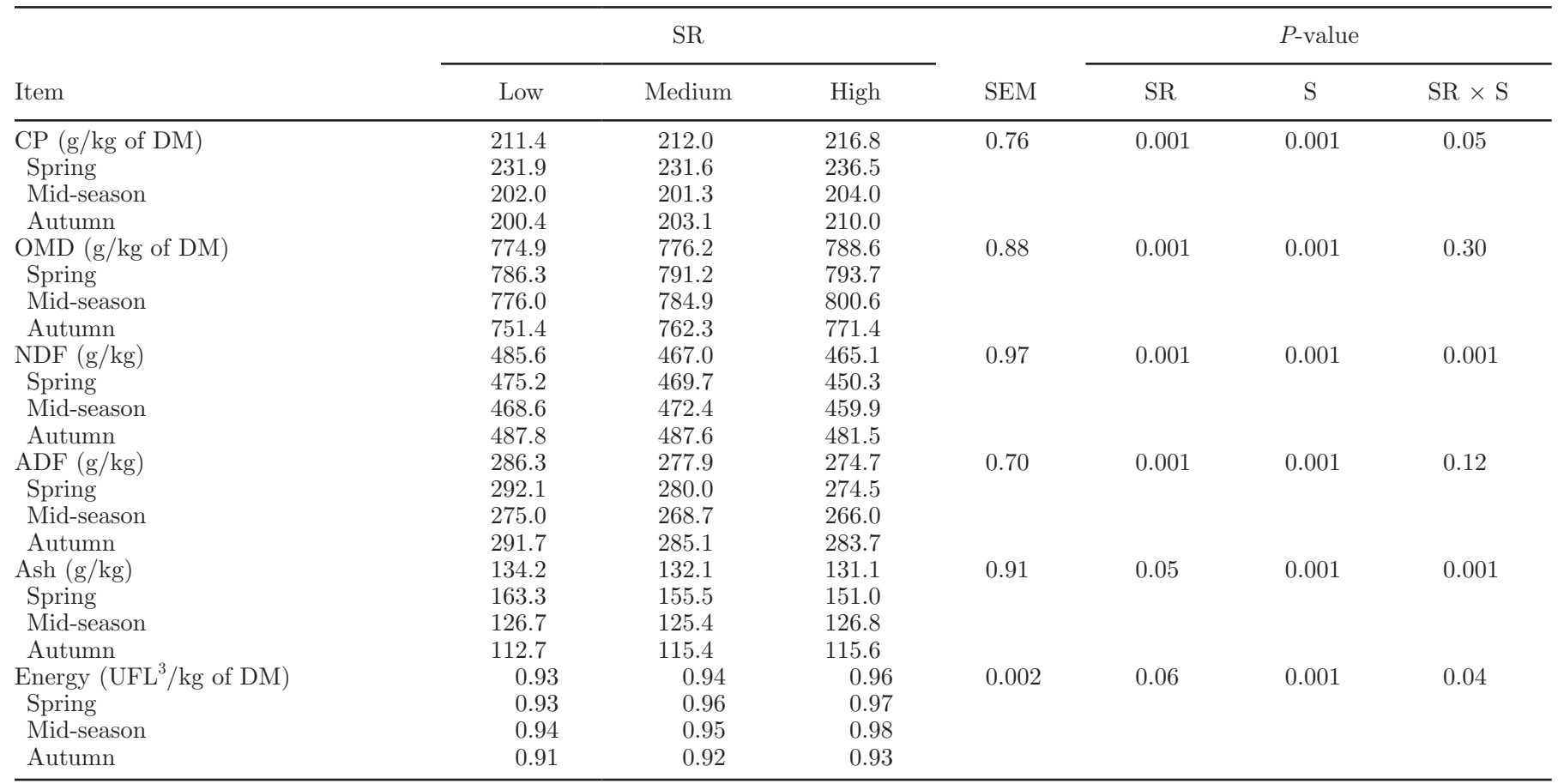

${ }^{1}$ Stocking rate: low $=2.51 \mathrm{cows} /$ ha, medium $=2.92 \mathrm{cows} /$ ha, high $=3.28 \mathrm{cows} / \mathrm{ha}$.

${ }^{2}$ Spring (February 1 to March 31), mid-season (April 1 to July 30), and autumn (August 1 to November 20).

${ }^{3} \mathrm{UFL}=$ unité fourragère lait. 
a)

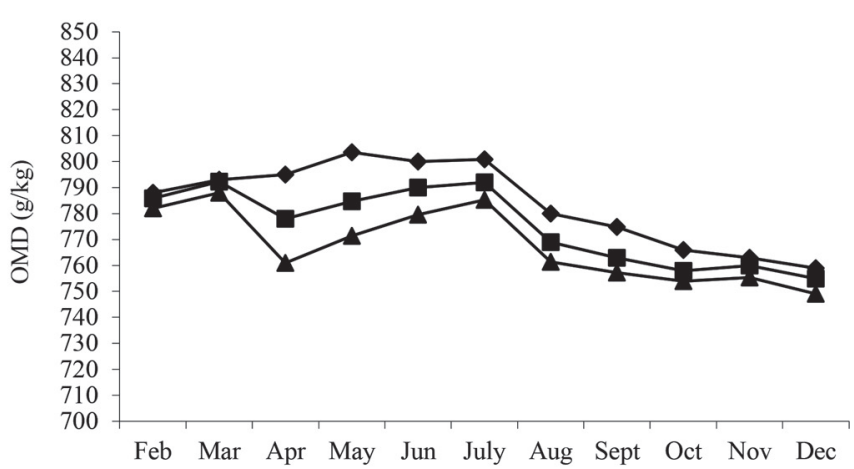

b)

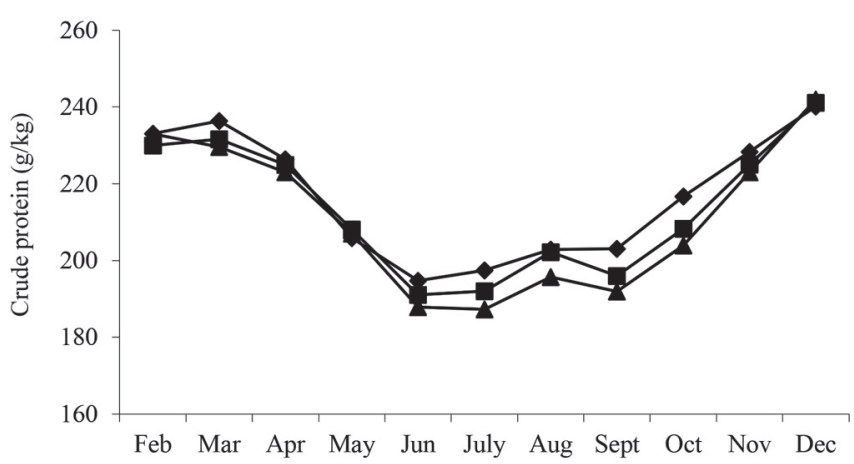

c)

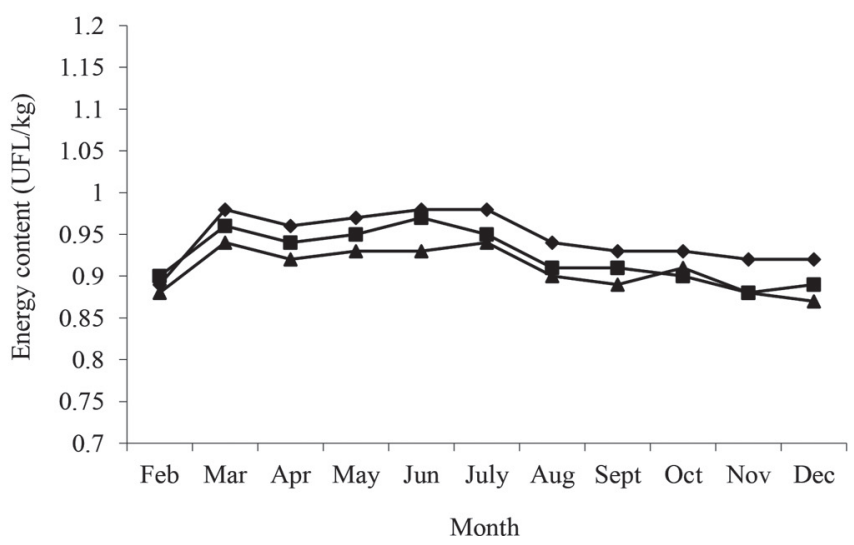

Figure 3. Effect of stocking rate $(\mathrm{SR})$ treatment (low $\mathrm{SR}=2.51$ cows/ha, $\mathbf{\Delta}$; medium $\mathrm{SR}=2.92$ cows/ha, $\mathbf{\square}$ and high $\mathrm{SR}=3.28$ cows/ ha, $\bullet$ ) on (a) mean monthly organic matter digestibility (OMD), (b) $\mathrm{CP}$ content, and (c) energy content in unité fourragère lait (UFL energy units) during the grazing season.

ly) and autumn (1,821 kg of DM/ha, $158 \mathrm{~kg}$ of DM/ha, and $40.5 \mathrm{~mm}$, respectively). Over the 4 -yr study period, grazed pasture utilization ( $\mathrm{kg}$ of $\mathrm{DM} / \mathrm{ha}$ ) increased linearly with increasing SR. Total pasture utilization did not differ significantly between treatments over the 4 -yr period $(12,468 \mathrm{~kg}$ of DM/ha; equivalent to 0.83 of net pasture accumulation). Average net pasture accumulated and utilized per rotation was greater for MSR (1,299 and 1,348 $\mathrm{kg}$ of $\mathrm{DM} /$ ha, respectively) and HSR (1,382 and 1,460 $\mathrm{kg}$ of DM/ha, respectively) compared with LSR (1,269 and 1,279 $\mathrm{kg}$ of DM/ha, respectively). Pasture grazing efficiency at each grazing event was greatest for the HSR (100\%) and least for LSR (84\%), whereas MSR was intermediate (92\%). Stocking rate had a significant effect on all seasonal feed utilization parameters. In spring, the HSR treatment achieved the lowest postgrazing residual pasture mass and $\mathrm{CSH}$ $(-202 \mathrm{~kg}$ of $\mathrm{DM} / \mathrm{ha}$ and $27.2 \mathrm{~mm}$, respectively) and the greatest grazing efficiency $(126 \%)$, compared with both the LSR (-134 $\mathrm{kg}$ of DM/ha, $30.0 \mathrm{~mm}$, and $117 \%$, respectively) and MSR ( $-162 \mathrm{~kg}$ of DM/ha, $28.9 \mathrm{~mm}$, and $120 \%$, respectively) treatments. Total pasture utilized was lower for LSR (920 kg of DM/ha) compared with both the MSR and HSR treatments (974 and $968 \mathrm{~kg}$ of DM/ha, respectively). Midseason pregrazing pasture masses were similar for each SR (1,419 kg of $\mathrm{DM} / \mathrm{ha})$. Both MSR and HSR treatments achieved greater quantities of pasture utilized (1,273 and 1,374 $\mathrm{kg}$ of DM/ha, respectively) due to reduced postgrazing residual pasture masses (137 and $22 \mathrm{~kg}$ of DM/ha, respectively) and CSH (40.1 and $35.9 \mathrm{~mm}$, respectively), and consequently increased grazing efficiency (90 and $98 \%$, respectively) compared with LSR (290 kg of DM/ ha, $45.8 \mathrm{~mm}$, and $80 \%$, respectively). Similarly, the higher SR treatments achieved increased quantities of pasture utilized (MSR, 1,619 kg of DM/ha; HSR, 1,768 $\mathrm{kg}$ of $\mathrm{DM} / \mathrm{ha}$ ) and increased grazing efficiency (MSR, 91\%; HSR, 98\%) in autumn compared with LSR (1,601 $\mathrm{kg}$ of DM/ha and $85 \%$, respectively) based on reduced postgrazing pasture masses (LSR, $279 \mathrm{~kg}$ of DM/ha; MSR, $157 \mathrm{~kg}$ of DM/ha; HSR, $38 \mathrm{~kg}$ of DM/ha) and increased grazing severity (LSR, $44.8 \mathrm{~mm}$; MSR, 40.4 $\mathrm{mm}$; HSR, $36.2 \mathrm{~mm}$ ). When pasture utilization was corrected for differences in nutritive value, cumulative grazed pasture and total energy utilization increased linearly with increasing SR. Net grazed and total energy utilized were greater for MSR (9,526 and 11,164 UFL/ha, respectively) and HSR (10,115 and 11,764 UFL/ha, respectively) compared with LSR (8,728 and $10,882 \mathrm{UFL} / \mathrm{ha}$, respectively). A significant linear effect $(P<0.01)$ of SR on total net energy utilization was detected with an increase of $1,027.4(\mathrm{SE}=289.00) \mathrm{UFL}$ utilized/ha for each $1 \mathrm{cow} /$ ha increase in SR.

\section{DISCUSSION}

Although many studies have reported the isolated and immediate effects of specific grazing practices (Lee et al., 2007; McEvoy et al., 2009; Ganche et al., 2013b) 
on various facets of pasture productivity, recent publications have highlighted the necessity for an integrated whole-farm systems approach to the evaluation of biological efficiencies within grazing systems (Clark et al., 2010; Baumont et al., 2014). Such experiments are difficult to interpret because of both the important effect of experimental decision rules and the interplay of factors that influence sward characteristics within integrated farm systems (Clark et al., 2010). In this study, the longer term and cumulative pasture productivity effects of alternate whole farm SR and grazing severity combinations were evaluated within whole-farm systems with limited external supplementary (feed and fertilizer) inputs over a 4-yr study period. Similar to Macdonald et al. (2008), and unlike classical SR experiments, the grazing management decision rules used in this experiment attempted to optimize the pasture performance within each SR treatment. Consequently, different target postgrazing residual CSH were adopted within this study to allow the SR effects to be consistently imposed. As a consequence, the results of this study indicate the likely implications of increasing SR when associated with an increase in grazing severity on pasture productivity. Although the differential in postgrazing sward height between treatments is relatively small in comparison with previous grazing severity comparisons (Binnie and Harrington, 1972; Grant et al., 1981), this differential represents the likely range of practical grazing severity within pasture-based systems at SR of 2.5 to 3.3 cows/ha and where up to $90 \%$ of the diet comes from grazed pasture (Ramsbottom et al., 2015).

Net pasture accumulation in this study is the sum of all pasture accumulated between successive grazings and incorporating winter growth between individual grazing seasons. Average net pasture accumulation of $14,977 \mathrm{~kg}$ of $\mathrm{DM} / \mathrm{ha}$ was realized over the $4 \mathrm{yr}$ of the current study and is indicative of excellent soil fertility (Tunney et al., 2010), proactive pasture renewal using high productivity ryegrasses (McEvoy et al., 2011), and best practice grazing management practices

Table 4. Effect of stocking rate $(\mathrm{SR})^{1}$ on cumulative and seasonal pasture characteristics and energy utilization ${ }^{2}$ during the 4 -yr study period

\begin{tabular}{|c|c|c|c|c|c|}
\hline \multirow[b]{2}{*}{ Item } & \multicolumn{3}{|c|}{$\mathrm{SR}$} & \multirow[b]{2}{*}{ SEM } & \multirow[b]{2}{*}{$P$-value } \\
\hline & Low & Medium & High & & \\
\hline \multicolumn{6}{|l|}{ Cumulative pasture utilization ( $\mathrm{kg}$ of $\mathrm{DM} / \mathrm{ha}$ per $\mathrm{yr}$ ) } \\
\hline Grazed pasture & 9,345 & 9,891 & 10,161 & 329.6 & 0.033 \\
\hline Conserved pasture & 2,988 & 2,454 & 2,524 & 295.2 & 0.213 \\
\hline Total & 12,320 & 12,358 & 12,726 & 256.5 & 0.233 \\
\hline Average pasture utilized (kg of DM/ha/rotation) & 1,279 & 1,347 & 1,460 & 12.1 & 0.001 \\
\hline Average grazing efficiency (\% utilization/rotation) & 84 & 92 & 100 & 0.3 & 0.001 \\
\hline \multicolumn{6}{|l|}{ Seasonal pasture utilization } \\
\hline \multicolumn{6}{|l|}{ Spring ${ }^{3}$} \\
\hline Pregrazing pasture mass ${ }^{4}(\mathrm{~kg}$ of $\mathrm{DM} / \mathrm{ha})$ & 785 & 812 & 766 & 19.3 & 0.26 \\
\hline Postgrazing residual pasture mass ${ }^{4}$ (kg of DM/ha) & -134 & -162 & -202 & 8.0 & 0.001 \\
\hline Pasture utilized (kg of DM/ha) & 920 & 974 & 968 & 24.0 & 0.10 \\
\hline Postgrazing residual $\mathrm{CSH}^{5}(\mathrm{~mm})$ & 30.0 & 28.9 & 27.2 & 0.33 & 0.001 \\
\hline Grazing efficiency (\%) & 117 & 120 & 126 & 1.5 & 0.001 \\
\hline \multicolumn{6}{|l|}{ Midseason ${ }^{3}$} \\
\hline Pregrazing pasture mass (kg of DM/ha) & 1,450 & 1,410 & 1,396 & 19.0 & 0.11 \\
\hline Postgrazing residual pasture mass ( $\mathrm{kg}$ of $\mathrm{DM} / \mathrm{ha})$ & 290 & 137 & 22 & 7.6 & 0.001 \\
\hline Pasture utilized (kg of DM/ha) & 1,160 & 1,273 & 1,374 & 15.7 & 0.001 \\
\hline Postgrazing residual CSH (mm) & 45.8 & 40.1 & 35.9 & 0.37 & 0.001 \\
\hline Grazing efficiency (\%) & 80 & 90 & 98 & 0.5 & 0.001 \\
\hline \multicolumn{6}{|l|}{ Autumn } \\
\hline Pregrazing pasture mass (kg of DM/ha) & 1,880 & 1,776 & 1,806 & 22.5 & 0.01 \\
\hline Postgrazing residual pasture mass ( $\mathrm{kg}$ of DM/ha) & 279 & 157 & 38 & 6.3 & 0.001 \\
\hline Pasture utilized (kg of DM/ha) & 1,601 & 1,619 & 1,768 & 19.5 & 0.001 \\
\hline Postgrazing residual CSH (mm) & 44.8 & 40.4 & 36.2 & 0.30 & 0.001 \\
\hline Grazing efficiency (\%) & 85 & 91 & 98 & 0.5 & 0.001 \\
\hline \multicolumn{6}{|l|}{ Cumulative energy utilization (UFL ${ }^{6} /$ ha per yr) } \\
\hline Grazed pasture & 8,728 & 9,526 & 10,115 & 344.8 & 0.001 \\
\hline Conserved pasture & 2,154 & 1,638 & 1,649 & 305.2 & 0.15 \\
\hline Total & 10,882 & 11,164 & 11,764 & 289.8 & 0.01 \\
\hline
\end{tabular}

${ }^{1}$ Stocking rate: low $=2.51$ cows $/$ ha, medium $=2.92 \mathrm{cows} /$ ha, high $=3.28$ cows $/$ ha.

${ }^{2}$ Estimated based on the method of Delaby and Peyraud (1998).

${ }^{3}$ Spring (February 1 to March 31), mid-season (April 1 to July 30) and autumn (August 1 to November 20).

${ }^{4}$ Estimated above $35 \mathrm{~mm}$ compressed sward height.

${ }^{5}$ Compressed sward height.

${ }^{6} \mathrm{UFL}=$ unité fourragère lait. 
a)

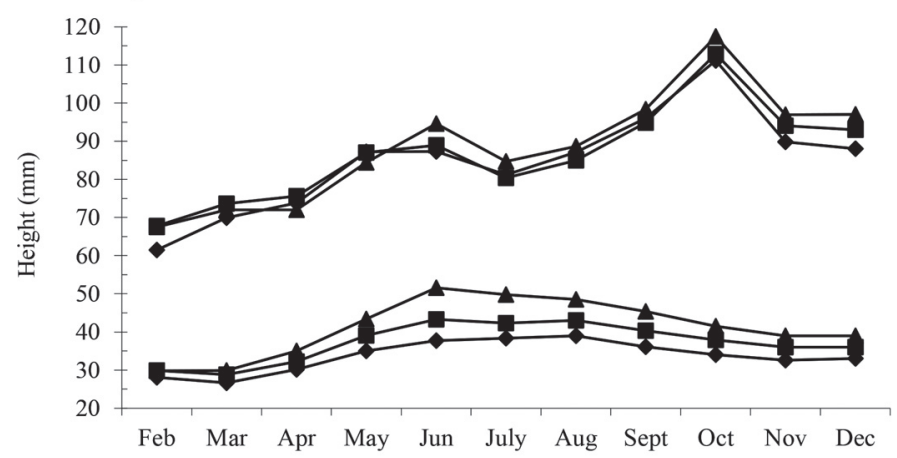

b)

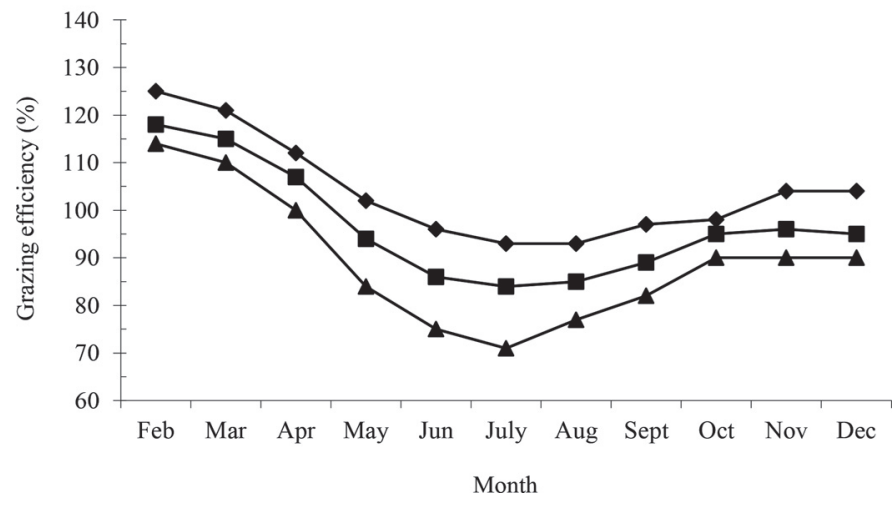

Figure 4. Effect of stocking rate (SR) treatment (low $\mathrm{SR}=2.51$ cows / ha, $\mathbf{\Delta}$; medium $\mathrm{SR}=2.92$ cows/ha, $\mathbf{\square}$; and high $\mathrm{SR}=3.28 \mathrm{cows} /$ ha, $\downarrow$ ) on (a) mean monthly pregrazing (upper figures) and postgrazing (lower figures) residual pasture heights, and (b) mean monthly grazing efficiency during the grazing season.

(Kennedy et al., 2009; Chapman et al., 2011; Ganche et al., 2013a). The overall level of pasture productivity achieved compares favorably with previous studies at this experimental site under comparable average climatic conditions and using lower levels of applied chemical fertilizer than previously reported (Dillon et al., 2005; McCarthy et al., 2007). In addition, the large range in annualized pasture yields for individual paddocks within each farmlet has also been reported previously and is indicative of the potential for further increases in pasture productivity within such systems (Clark et al., 2010; 9,500 to 26,100 kg of DM/ha per yr). In comparison with the LSR, the imposition of a consistently increased grazing severity coupled with increased whole farm SR in MSR and HSR treatments resulted in a significant increase in annual net pasture accumulation $(+0.035$ and +0.064 , respectively) over the 4-yr period. Previous studies have provided conflicting evidence of the effect of defoliation severity on pasture accumulation, and the interpretation of reported results is complicated by variation in previous pasture management (pregrazing pasture masses, rota- tion lengths, grazing severity, and so on). Michell and Fulkerson (1987) reported that severe grazing severity reduced net pasture accumulation and has been associated with a substantial reduction in the rate of photosynthesis (Brougham, 1956; Parsons et al., 1988) due to the removal of all leaf material. In contrast, Ganche at al. (2013b) reported no detrimental effect of grazing severity on annual pasture accumulation when postgrazing residual $\mathrm{CSH}$ of 27,35 , and $42 \mathrm{~mm}$ were compared in spring, and Lee et al. (2007) similarly reported no negative effect of severe grazing residuals on subsequent pasture accumulation. In addition, both Kristensen (1988) and Parsons et al. (2000) have reported accelerated pasture regrowth following severe defoliation of high leaf content perennial ryegrass pastures and Lee et al. (2008) reported a quadratic effect of postgrazing residual pasture mass on pasture accumulation, with pasture accumulation declining at either excessively low (20 $\mathrm{mm})$ or high $(80 \mathrm{~mm}) \mathrm{CSH}$ grazing residuals. The beneficial effect of increased grazing severity, particularly in spring, and increased SR on cumulative pasture accumulation was linear and equivalent to an increase in net herbage accumulation of $1,164 \mathrm{~kg}$ of DM/ha for a $1 \mathrm{cow} / \mathrm{ha}$ increase in SR. The results of this study are consistent with the findings of Macdonald et al. (2008) within a similar multi-year SR experiment, who reported a linear increase of $986 \mathrm{~kg}$ of $\mathrm{DM} / \mathrm{ha}$ for every $1 \mathrm{cow} /$ ha increase in SR. Higher summer regrowth rates have also been reported for pastures that were severely grazed in the spring (Michell and Fulkerson, 1987), and this has been associated with an increase in the number of developed vegetative tillers within the pasture (Korte et al., 1984). Furthermore, the existence of a significant SR effect on net pasture accumulation suggest that future grazing research should increasingly consider the longer term and potentially cumulative effects of alternate grazing management practices within farm systems that are imposed over multiple grazing seasons to incorporate the cumulative conditioning and adaptation effects on pastures arising from consistently imposed treatments.

The consistently increased immediate regrowth rate of plant tissue following more severe defoliation (Figure 2) of higher SR treatments was also associated with an increase in leaf content $(+0.10)$ and a reduction in sheath length within the high SR pastures of this study (Tuñon et al., 2014). The increased regrowth rate may have been due to increased photosynthesis capacity of residual leaf laminae and pseudostem and changes in gene expressions associated with carbohydrate metabolism within the consistently severely grazed higher SR pastures (Booysen and Nelson, 1975; Lee et al., 2011). Similarly, Chapman and Lemaire (1993) concluded that where ryegrass pastures were continuously 
severely defoliated, the pasture adapted to maximize leaf area in the sub-grazing horizon by reducing sheath length and maintaining additional leaf tissue below the grazing height to increase photosynthetic capability and accelerate regrowth. The beneficial effects of the higher SR treatments on net pasture accumulation within this study are also consistent with the conceptual model of pasture growth and senescence proposed by Bircham and Hodgson (1983) and indicates that, although pregrazing pasture mass tends to increase within laxly grazed pastures, net pasture accumulation is reduced, as increased quantities of residual stem and decaying material that are less photosynthetically active than younger leaves (Gay and Thomas, 1995; Lee et al., 2007) are contained within the regrown material. Similarly, L'Huillier (1987) reported that whereas total (live and dead) pasture accumulation increased in laxly grazed pastures, green (total less senescent) pasture accumulation was unaffected by grazing severity.

The immediate positive effect of severe defoliation on sward nutritive value (and in particular in ADF, NDF, OMD, and UFL) within both higher SR and more severely defoliated pastures, both individually and collectively, has been reported previously (Stakelum and Dillon, 2007; Macdonald et al., 2008; Peyraud and Delagarde, 2013). The general seasonal effects on sward nutritive value have also been widely reported (Hacker and Minson, 1981; Korte et al., 1984; Coleman et al., 2010). The magnitude of the nutritive value superiority of higher SR pastures in mid-season and autumn within this study is also similar to previous studies. Stakelum and Dillon (1990) reported an increase of $39 \mathrm{~g} / \mathrm{kg}$ of DM in OMD within leafy vegetative high SR mid-season pastures and Lee et al. (2007) reported an increase of $29 \mathrm{~g} / \mathrm{kg}$ of DM in OMD within more severely grazed pastures. Likewise, both Stakelum and Dillon (1990) and O'Donovan and Delaby (2008) reported greater OMD values within pastures that were grazed to low relative postgrazing heights and hence had greater proportions of live leaf and less senescent material. Consistent with these previous studies, the current results illustrate the potential for more severe grazing at higher SR to efficiently harvest pastures during the early reproductive stage to arrest the decline in sward nutritive value, typically reported during midseason (Korte et al., 1984; Gibb et al., 1989; Tuñon et al., 2014). Notwithstanding the beneficial effects of SR treatment on sward nutritive value, the nutritive value within the LSR pastures of the current study was also high relative to previous studies (Stakelum and Dillon, 2007; O'Donovan and Delaby, 2008) and is indicative of the relatively narrow differential in grazing residuals between treatments within this study, particularly dur- ing spring and autumn. Consequently, whereas many other grazing severity component studies have reported a substantial decline in sward nutritive value and botanical composition within laxly grazed pastures and recommended that such residual material be mechanically removed (Stakelum, 1996), these results indicate that the judicious use of silage conservation after inflorescence may be an effective strategy to correct and maintain pasture nutritive value within LSR pastures and can possibly negate the requirement for additional mechanical intervention (topping). In comparison with the pronounced effect of SR treatment on net pasture accumulation, sward nutritive value was not consistently higher due to the increased grazing severities within this study.

In addition to the increase in net pasture accumulation and improved sward nutritive value at higher SR, the lower postgrazing residual CSH of the MSR and HSR treatments, resulted in an increase in grazing efficiency and grazed pasture utilization within the higher SR treatments, as additional grazing animals consumed an increasing proportion of the available pasture. Similar to previous studies (Ganche et al., 2013a; Tuñon, 2013), the efficiency of pasture utilization under grazing (grazing efficiency; pasture utilized/pregrazing pasture mass $>3.5 \mathrm{~cm}$ ) increased as SR increased within the present study. Although it is widely accepted that an increase in pasture utilization can be achieved by decreasing postgrazing residual CSH (Pérez-Prieto et al., 2011; Ganche et al., 2013b) or increasing SR, or both (McMeekan and Walsh, 1963; Fales et al., 1995; Macdonald et al., 2008), the total quantity of feed utilized ( $\mathrm{kg}$ of DM/ha) is seldom reported. Within an overall farm systems context, the overall effect of SR treatment on total pasture utilization $(\mathrm{kg}$ of $\mathrm{DM} / \mathrm{ha})$ is complicated by the differential requirements for grazed pasture between SR treatments, and consequently, the utilization of pasture as conserved pasture silage must also be considered (Fales et al., 1995; Macdonald et al., 2008). Similar to both Valentine et al. (2009) and Farina et al. (2011), grazed pasture utilization and grazing efficiency increased at higher SR and total pasture utilization (grazed plus conserved pasture; $\mathrm{kg}$ of DM/ha) was unaffected by SR within systems where surplus pasture was efficiently removed and conserved as silage. Consequently, and similar to Macdonald et al. (2008), total pasture utilization (expressed as a proportion of net pasture utilization) was consistently 0.8 of the net pasture accumulation across all SR treatments. Furthermore, when grazed and conserved pasture utilization were adjusted to incorporate the additional beneficial effects on pasture energy value (UFL content) and pasture utilization efficiency, the total proportional 
energy utilization per ha was significantly increased at higher SR $(+0.026$ and +0.081 for MSR and HSR, respectively).

The detailed measurement methodology adopted in this study allows the accumulated effects of alternate grazing strategies to be accurately quantified over 4 complete grazing seasons. These results indicate that grazing management practices have an important effect on the feed production capability of modern perennial ryegrass pastures for intensive grazing dairy production systems.

\section{CONCLUSIONS}

In the range of treatments studied, increased SR in combination with increased grazing severity resulted in grassland pastures of higher productivity characterized by increased annual net pasture accumulation, improved pasture nutritive value, and increased grazed pasture and energy utilization capacity. Furthermore, these results suggest that future grazing research should increasingly consider the longer term effects of consistently imposed grazing management practices within farm systems over multiple grazing seasons to incorporate the potentially cumulative conditioning and adaptive effects on pastures productivity.

\section{ACKNOWLEDGMENTS}

The authors express their appreciation and deep affection for Michael Feeney, who was so vital to the research project team and who sadly passed away during this study. We also thank F. Flynn, P. O'Connor, and C. Fleming (Animal and Grassland Research and Innovation Centre, Teagasc, Moorepark, Fermoy, Co. Cork, Ireland) for their technical assistance and the staff of Curtins Farm, Moorepark for their co-operation, care, and management of the experimental area. The authors acknowledge funding from the Irish Farmers Dairy Levy and the Teagasc Walsh Fellowship Programme.

\section{REFERENCES}

Adler, P. B., D. A. Raff, and W. K. Lauenroth. 2001. The effect of grazing on the spatial heterogeneity of vegetation. Oecologia 128:465-479.

Allen, V. G., C. Batello, E. J. Berretta, J. Hodgson, M. Kothmann, X. Li, J. McIvor, J. Milne, C. Morris, A. Peeters, M. Sanerson, and The Forage and Grazing Terminology Committee. 2011. An international terminology for grazing lands and grazing animals. Grass Forage Sci. 66:2-28.

Anderson, V. J., and D. D. Briske. 1995. Herbivore-induced species replacement in grasslands: Is it driven by herbivory tolerance or avoidance? Ecol. Appl. 5:1014-1024.

Baudracco, J., N. Lopez-villalobos, C. W. Holmes, and K. A. Macdonald. 2010. Effects of stocking rate, supplementation, genetic strain and their interactions on grazing dairy systems: A review. N.Z. J. Agric. Res. 53:109-133.

Baumont, R., E. Lewis, L. Delaby, S. Prache, and B. Horan. 2014. Sustainable intensification of grass-based ruminant production. Pages 521-534 in Grassland Science in Europe, Vol. 19. EGF at 50: the Future of European Grasslands. A. Hopkins, R. P. Collins, M. D. Fraser, V. R. King, D. C. Lloyd, J. M. Moorby, and P. R. H. Robson, ed. European Grassland Federation, Zurich, Switzerland.

Beaumont, R., J. P. Dulphy, D. Sauvant, F. Meschy, J. Aufrere, and J. L. Peyraud. 2007. Valeur alimentaire des fourrages et des matieres premieres: Tables et prevision. Pages 149-180 in Alimentation des Bovins, Ovins et Caprins. QUAE Editions. Institut National de Recherche Agronomique, Versailles, France.

Binnie, R. C., and F. J. Harrington. 1972. The effect of cutting height and cutting frequency on the productivity of an Italian ryegrass sward. Grass Forage Sci. 27:177-182.

Bircham, J. S., and J. Hodgson. 1983. The influence of swards condition on rates of herbage growth and senescence in mixed swards under continuous stocking management. Grass Forage Sci. 38:323331.

Booysen, P. V., and C. J. Nelson. 1975. Leaf area and carbohydrate reserves in regrowth of tall fescue. Crop Sci. 15:262-266.

Brougham, R. W. 1956. Effects of intensity of defoliation on regrowth of pasture. Aust. J. Agric. Res. 7:377-387.

Byrne, E. 1979. Chemical Analysis of Agricultural Materials. An Foras Taluntais, Dublin, 194.

Chapman. D. F., S. N. Kenny, and N. L. Lane. 2011. Pasture and forage crop systems for non-irrigated dairy farms in southern Australia. 3. Estimated economic value of additional home grown feed. Agric. Syst. 104:589-599.

Chapman, D. F., and G. Lemaire. 1993. Morphogenetic and structural determinants of plant regrowth after defoliation. Pages 95-104 in Proc. 17th Int. Grassland Congr. Vol. 1. M. J. Baker, J. R. Crush, and L. R. Humphreys, ed. New Zealand and Australia.

Clark, C. E. F., A. J. Romera, K. A. Macdonald, and D. A. Clark. 2010. Inter-paddock annual dry matter yield variability for dairy farms in the Waikato region of New Zealand. N. Z. J. Agric. Res. $53: 187-191$.

Coakley, M., E. Barrett, J. J. Murphy, R. P. Ross, R. Devery, and C. Stanton. 2007. Cheese with elevated CLA levels: Hard cheese manufacture with milk with elevated conjugated linoleic acid levels due to dietary manipulation. J. Dairy Sci. 90:2919-2927.

Coleman, J., K. M. Pierce, D. P. Berry, A. Brennan, and B. Horan. 2010. Increasing milk solids production across lactation through genetic selection and intensive pasture-based feed system. J. Dairy Sci. 93:4302-4317.

Dartt, B. A., J. W. Lloyd, B. R. Radke, J. R. Black, and J. B. Kaneene. 1999. A comparison of profitability and economic efficiencies between management intensive grazing and conventionally managed dairies in Michigan. J. Dairy Sci. 82:2412-2420.

Delaby, L., and J. L. Peyraud. 1998. Effect d'une réduction simultanée de la fertilisation azotée et du chargement sur les performances des vaches laitières et la valorisation du pâturage (Effect of a simultaneous reduction in nitrogen fertilization and stocking rate on the performance of dairy cows and pasture utilization). Ann. Zootech. 47:17-39.

Delgado, C. L. 2005. Rising demand for meat and milk in developing countries: implications for grasslands-based livestock production. Pages 29-39 in Grassland: A Global Resource. D. A. McGilloway, ed. Wageningen Academic Publishers, Wageningen, the Netherlands.

Dillon, P., T. Hennessy, L. Shalloo, F. Thorne, and B. Horan. 2008. Future outlook for the Irish dairy industry: A study of international competitiveness, influence of international trade reform and requirement for change. Int. J. Dairy Technol. 61:16-29.

Dillon, P., J. R. Roche, L. Shalloo, and B. Horan. 2005. Optimising financial return from grazing in temperate pastures. Pages 131147 in Utilisation of grazed grass in temperate animal systems. Proceedings of a satellite workshop of the XXth International Grassland Congress, July 2005, Cork, Ireland. J. J. Murphy, ed. Wageningen Academic Publishers, Wageningen, the Netherlands. 
Donaghy, D. J., and W. J. Fulkerson. 1998. Priority for allocation of water-soluble carbohydrate reserves during regrowth of Lolium perenne. Grass Forage Sci. 53:211-218.

Fales, S. L., L. D. Muller, S. A. Ford, M. O'Sullivan, R. J. Hoover, L. A. Holden, L. E. Lanyon, and D. R. Buckmaster. 1995. Stocking rate affects production and profitability in a rotationally grazed pasture system. J. Prod. Agric. 8:88-96.

Farina, S. R., S. C. Garcia, W. J. Fulkerson, and I. M. Barchia. 2011. Pasture-based dairy farm systems increasing milk production through stocking rate or milk yield per cow: Pasture and animal responses. Grass Forage Sci. 66:316-332.

Ganche, E., L. Delaby, M. O'Donovan, T. Boland, and E. Kennedy 2013a. Direct and carryover effect of post-grazing sward height on total lactation dairy cow performance. Animal 7:1390-1400.

Ganche, E., L. Delaby, M. O'Donovan, T. M. Boland, N. Galvin, and E. Kennedy. 2013b. Post-grazing sward height imposed during the first 10 weeks of lactation: Influence on early and total lactation dairy cow production, and spring and annual sward characteristics. Livest. Sci. 157:299-311.

Gay, A. P., and H. Thomas. 1995. Leaf development in Lolium temulentum L.: Photosynthesis in relation to growth and senescence. New Phytol. 130:159-168.

Gibb, M. J., R. D. Baker, and A. M. E. Sayer. 1989. The impact of grazing severity on perennial ryegrass/white clover swards stocked continuously with beef cattle. Grass Forage Sci. 44:315-328.

Grant, S. A., G. T. Barthram, and L. Torvell. 1981. Components of regrowth in grazed and cut Lolium perenne swards. Grass Forage Sci. 36:155-168.

Hacker, J. B., and D. J. Minson. 1981. The digestibility of plant parts. Herbage Abstr. 51:459-482.

Heubsch, M., B. Horan, P. Blum, K. G. Richards, J. Grant, and O. Fenton. 2013. Impact of agronomic practices of an intensive dairy farm on nitrogen concentrations in a karst aquifer in Ireland. Agric. Ecosyst. Environ. 179:187-199.

Hoden, A., J. L. Peyraud, A. Muller, L. Delaby, and P. Faverdin. 1991. Simplified rotational grazing management of dairy cows: Effects of rates of stocking and concentrate. J. Agric. Sci. 116:417-428.

Hoogendoorn, C. J., C. W. Holmes, and A. C. P. Chu. 1992. Some effects of herbage composition, as influenced by previous grazing management, on milk production by cows grazing on ryegrass/ white clover pastures. 2. Milk production in late spring/summer: Effects of grazing intensity during the preceding spring period. Grass Forage Sci. 47:316-325.

Horan, B., P. Dillon, P. Faverdin, L. Delaby, F. Buckley, and M. Rath. 2005. The interaction of strain of Holstein-Friesian cows and pasture based feed systems on milk yield, body weight, and body condition score. J. Dairy Sci. 88:1231-1243.

Jankowska-Huflejt, H. 2006. The function of permanent grasslands resources protection. J. Water Land Dev. 10:55-65.

Jeangros, B., and P. Thomet. 2004. Multi-functionality of grassland systems in Switzerland. Grassland Sci. Europe 9:11-23.

Kennedy, E., M. McEvoy, J. P. Murphy, and M. O'Donovan. 2009 Effect of restricted access time to pasture on dairy cow milk production grazing behaviour, and dry matter intake. J. Dairy Sci. 92:168-176.

Korte, C. J., B. R. Watkin, and W. Harris. 1984. Effects of timing and intensity of spring grazing on reproductive development, tillering and herbage production of ryegrass dominant pasture. N. Z. J. Agric. Res. 27:135-149.

Kristensen, E. S. 1988. Influence of defoliation regime on herbage production and characteristics of intake by dairy cows as affected by grazing severity. Grass Forage Sci. 43:239-251.

L'Huillier, P. 1987. Effect of dairy cattle stocking rate and degree of defoliation on herbage accumulation and quality in ryegrassWhite clover pasture. N. Z. J. Agric. Res. 30:149-157.

Laca, E. A., and M. W. Demment. 1991. Herbivory: The dilemma of foraging in a spatially heterogeneous food environment. Pages 29-44 in Plant Chemical Defences Against Mammalian Herbivory. T. Palo and C. Robbins, ed. CRC Press, Boca Raton, FL.

Lee, J., D. J. Donaghy, and J. R. Roche. 2007. The effect of grazing severity and fertiliser application during winter on herbage regrowth and quality of perennial ryegrass (Lolium perenne L.). Aust. J. Exp. Agric. 47:825-832.

Lee, J. M., D. J. Donaghy, and J. R. Roche. 2008. Effect of defoliation severity on regrowth and nutritive value of perennial ryegrass dominant swards. Agron. J. 100:308-314.

Lee, J. M., D. J. Donaghy, P. Sathish, and J. R. Roche. 2009. Interaction between water-soluble carbohydrate reserves and defoliation severity on the regrowth of perennial ryegrass (Lolium perenne L.) dominant swards. Grass Forage Sci. 64:266-275.

Lee, J. M., D. J. Donaghy, P. Sathish, and J. R. Roche. 2011. Impact of defoliation severity on photosynthesis, carbon metabolism and transport gene expression in perennial ryegrass. Funct. Plant Biol. $38: 808-817$

Macdonald, K. A., J. W. Penno, J. A. S. Lancaster, and J. R. Roche. 2008. Effect of stocking rate on pasture production, milk production and reproduction of dairy cows in pasture-based systems. J. Dairy Sci. 91:2151-2163.

McCarthy, B., L. Delaby, K. M. Pierce, A. Brennan, and B. Horan. 2013a. The effect of stocking rate and calving date on milk production of Holstein-Friesian dairy cows. Livest. Sci. 153:123-134.

McCarthy, B., K. M. Pierce, L. Delaby, A. Brennan, C. Fleming, and B. Horan. 2013b. The effect of stocking rate and calving date on grass production, utilization and nutritive value of the sward during the grazing season. Grass Forage Sci. 68:364-377.

McCarthy, B., K. M. Pierce, L. Delaby, A. Brennan, and B. Horan 2012. The effect of stocking rate and calving date on reproductive performance, body state, and metabolic and health parameters of Holstein- Friesian dairy cows. J. Dairy Sci. 95:1337-1348.

McCarthy, S., B. Horan, P. Dillon, P. O'Connor, M. Rath, and L. Shalloo. 2007. An economic comparison of three divergent strains of Holstein-Friesian dairy cows in various pasture based milk production systems. J. Dairy Sci. 90:1493-1505.

McEvoy, M., M. O'Donovan, E. Kennedy, J. P. Murphy, L. Delaby, and T. M. Boland. 2009. Effect of pre grazing herbage mass and pasture allowance on the lactation performance of Holstein-Friesian dairy cows. J. Dairy Sci. 92:414-422.

McEvoy, M., M. O'Donovan, and L. Shalloo. 2011. Development and application of an economic ranking index for perennial ryegrass cultivars. J. Dairy Sci. 94:1627-1639.

McMeekan, C. P., and M. J. Walsh. 1963. The inter-relationships of grazing method and stocking rate in the efficiency of pasture utilization by dairy cattle. J. Agric. Sci (Camb.) 61:147-166.

Michell, P., and W. J. Fulkerson. 1987. Effect of grazing intensity in spring on pasture growth, composition and digestibility, and on milk production by dairy cows. Aust. J. Exp. Agric. 27:35-40.

Morgan, D. J., G. Stakelum, and J. Dwyer. 1989. Modified neutral detergent cellulase digestibility procedure for use with the fibretec system. Isr. J. Agric. Res. 28:91-92.

Nosberger, J., and M. Rodriguez. 1996. Increasing biodiversity through management. Grassland Sci. Europe 1:949-956.

O'Brien, B., P. Dillon, J. J. Murphy, R. K. Mehra, T. P. Guinee, J. F Connolly, A. Kelly, and P. Joyce. 1999. Effects of stocking density and concentrate supplementation of grazing dairy cows on milk production, composition and processing characteristics. J. Dairy Res. 66:165-176.

O'Donovan, M. 2000. The relationship between the performance of dairy cows and grassland management on intensive dairy farms in Ireland. PhD thesis. National University of Ireland, Dublin, Ireland.

O'Donovan, M., and L. Delaby. 2008. Sward characteristics, grass dry matter intake and milk production performance is affected by timing of spring grazing and subsequent stocking rate. Livest. Sci. 115:158-168.

Parsons, A. J., P. Carre`re, and S. Schwinning. 2000. Dynamics of heterogeneity in a grazed sward. Pages 289-315 in Grassland Ecophysiology and Grazing Ecology. G. Lemaire, J. Hodgson, A. de Moraes, C. Nabinger, and P. C. de F. Carvalho, ed. CAB International, Wallingford, UK.

Parsons, A. J., I. R. Johnson, and A. Harvey. 1988. Use of a model to optimize the interaction between frequency and severity of intermittent defoliation and to provide a fundamental comparison of 
the continuous and intermittent defoliation of grass. Grass Forage Sci. 43:49-59.

Peech, M., and L. English. 1944. Rapid microbiological soil tests. Soil Sci. 57:167-195.

Pérez-Prieto, L. A., J. L. Peyraud, and R. Delagarde. 2011. Substitution rate and milk yield response to corn silage supplementation of late-lactation dairy cows grazing low-mass pastures at 2 daily allowances in autumn. J. Dairy Sci. 94:3592-3604.

Peyraud, J. L., and R. Delagarde. 2013. Managing variations in dairy cow nutrient supply under grazing. Animal 7:57-67.

Peyraud, J. L., A. Van Den Pol-van Dasselaar, P. Dillon, and L. Delaby. 2010. Producing milk from grazing to reconcile economic and environmental performances. Grassl. Sci. Europe. 15:865-879.

Possingham, P. H., and A. I. Houston. 1990. Optimal patch use by a territorial forager. J. Theor. Biol. 145:343-353.

Pulido, R. G., and J. D. Leaver. 2003. Continuous and rotational grazing of dairy cows - The interactions of grazing system with level of milk yield, sward height and concentrate level. Grass Forage Sci. $58: 265-275$.

Rae, A. N. 2002. The role of grasslands in world food trade: Projections of future trade policy reforms. N. Z. J. Agric. Res. 45:35-47.

Ramsbottom, G., B. Horan, D. P. Berry, and J. R. Roche. 2015. Factors associated with the financial performance of spring-calving, pasture-based dairy farms. J. Dairy Sci. 98:3526-3540.

Roche, J. R., L. R. Turner, J. M. Lee, D. C. Edmeades, D. J. Donaghy, K. A. Macdonald, J. W. Penno, and D. P. Berry. 2009. Climate, herbage quality and milk production in pastoral systems. 2. Temporal patterns and intra-relationships in herbage quality parameters. Anim. Prod. Sci. 49:200-210.

Stakelum, G. 1996. Practical grazing management for dairy cows. Irish Grassland Animal Produc. Assoc. J. 30:33-45.

Stakelum, G., and P. Dillon. 1990. Influence of sward structure and digestibility on intake and performance of lactating and growing cattle. Pages 30-40 in Grassland Management Priorities: Management Issues for the Grassland Farmer in the 1990's. C. S. Mayne ed. British Grassland Society, Hurley.

Stakelum, G., and P. Dillon. 2007. The effect of grazing pressure on rotationally grazed pastures in spring/early summer on subsequent sward characteristics. Ir. J. Agric. Food Res. 46:15-28.

Taube, F., M. Gierus, A. Hermann, R. Loges, and P. Schönbach. 2013. Grassland and globalization-Challenges for north-west European grass and forage research. Grass Forage Sci. 69:2-16.

Teagasc. 2009. Grazing notebook, recommended nitrogen rates and timings throughout the grazing season. Cork, Ireland.

Tunney, H., L. Kirwan, W. Fu, N. Culleton, and A. D. Black. 2010 Long term phosphorus grassland experiment for beef productionImpacts on soil phosphorus levels and liveweight gains. Soil Use Manage. 26:237-244.

Tuñon, G., E. Kennedy, B. Horan, D. Hennessy, N. Lopez-Villalobos, P. Kemp, A. Brennan, and M. O'Donovan. 2014. Effect of grazing severity on perennial ryegrass herbage production and sward structural characteristics throughout an entire grazing season. Grass Forage Sci. 69:104-118.

Tuñon, G. E. 2013. Improving the use of perennial ryegrass swards for dairying in Ireland. Doctoral dissertation. Massey University, Palmerston North, New Zealand.

Valentine, S., P. Lewis, R. T. Cowan, and J. Defaveri. 2009. The effects of high stocking rates on milk production from dryland and irrigated Mediterranean pastures. Anim. Prod. Sci. 49:100-111.

Van Soest, P. J. 1963. Use of detergents in the analysis of fibrous feeds. II. A rapid method for the determination of fibre and lignin. J. Assoc. Off. Agric. Chem. 46:829-835.

White, S. L., G. A. Benson, S. P. Washburn, and J. T. Green Jr.. 2002. Milk production and economic measures in confinement or pasture systems using seasonally calved Holstein and Jersey cows. J. Dairy Sci. 85:95-104. 